\title{
SOCIO-EDUCATIONAL CONTEXTS OF THE QUALITY OF LIFE OF SENIORS
}

\author{
Katarzyna Jagielska \\ Pedagogical University of Cracow, Poland
}

\begin{abstract}
One of the most important phenomena of the changing world is aging of population. With the growing number of older people it is necessary to focus on this part of population. It is also important to allow seniors active participation in social life. The aging population provides us with many interesting materials for scientific consideration and one of them is the socio-educational contexts of the seniors' quality of life. The purpose of this study is to analyse the theoretical basis of quality of life of seniors and to highlight the relevant factors affecting the quality of life in relation to older people. In this paper it is shown how education can affect the quality of life of older people not only in terms of acquiring new knowledge, but also in the context of establishing social relations and social activation. The study focous on a theoretical study and an attempt to analyse the available data on the participation of Polish seniors in education.
\end{abstract}

Keywords: ageing population, education, quality of life, seniors.

\section{Introduction}

Contemporary world is marked with a dynamic change with a move of demographic structure inscribed in its trend. In recent years one can observe an increase of the number of elderly people in the population. Statistical data implies that their share in the general population of Poland was $14.7 \%$ in 2013 (among 38 million inhabitants the elderly are 5.7 million). Demographic forecasts of the Central Statistical Office of Poland (GUS) state that until 2050 the share of elderly people in the general population will increase up to $32.7 \%$ (Rutkowska, p.35). The phenomenon of "aging" of the society is not only a consequence of the generations of "demographic heights" entering the demographic elderly age but a considerable role is played by prolonging the life span as a result of technological development, modern diagnostic methods, better access to medical health care and propagation of healthy and active life styles. According to GUS data average life expectancy in Poland in 2014 was 73.8 years for a man and 81.6 years for a woman (Central Statistical Office of Poland (GUS), 2015). Researchers predict that men born in 2050 will, on average, have 81.1 years of life ahead while an average life expectancy of a woman will reach 87.5 years. From the point of view of an elderly person's quality of life issue the fact of the percentage increase of the elderly in the 
general population or the fact of the average life expectancy being prolonged are not the only important phenomena. Polymorphism among the elderly has gained a vital role as well. The subpopulation of the elderly is internally differentiated (Pikuła, 2014, 309-316). It is demonstrated by, among other, an increase of the percentage of the elderly in particular age groups and also in a differentiated health, family or social functioning situation, etc. In recent years one can observe a fast pace of the increase of the percentage of seniors in the subpopulation of 80-year-olds and older (the percentage of the elderly in that group doubled and increased from $2 \%$ up to $4 \%$ ). The dynamics of the elderly percentage increase in the younger age group (65-79) is lower and it grew from $8 \%$ to almost $11 \%$ within 25 years (Rutkowska, 2014, 35). The time of old age life has prolonged, which bears vital consequences for quality of life of the elderly. At the initial stage of the old age they are not so evident but they change together with age. That differentiation is an effect of changes caused by the man's aging process. In the old age the man encounters a lot of health problems, changes in his mental welfare, a diminishing level of fitness being a result of the aging process (and indirectly, of the lifestyle). Changing social roles, going to pension, changing the family situation often influences social relationships and activity of the elderly in a negative way. An additional factor negatively influencing the functioning of the elderly is a threat of stereotyping (negative social imaging may paralyze to such an extent that people present their abilities below their own (Trusz, 2015, 18). The presented factors have crucial influence on quality of life of the elderly so it is important from the point of view of scientific considerations to introduce such measures which will add up to bettering the life of seniors. The undertaken actions should have a long-lasting character. The evaluation of the current demographic situation, knowledge of the problems of nowadays' seniors and being acquainted with demographic forecasts and the increase of polymorphism in the subpopulation of the elderly may bring visible effects for acting towards bettering quality of life of seniors.

The aim of this paper is presenting social-educational contexts of the quality of life of seniors. The paper has a theoretical dimension but it will depict the data which show social-educational activity of seniors in Poland. The article describes the most important determiners of quality of life and stresses the role of educational and social activity of the elderly in their everyday life. Hence, according to the author, the actions conducted towards the elderly should be an answer to their needs. The main support should, therefore, be directed at inspirational activities which would encourage the elderly towards active life that is a condition of high quality of life. To influence quality of life betterment one should be educated for old age since such long-lasting activities may bring a considerable result. As Aleksander Kamiński mentions, by education for old age we help "people in acquiring interests and aspirations as well as skills and 
habits, which, when the pension time comes, will help in realizing the lifestyle favoring prolonging the youthhood and give satisfaction of activity" (Kamiński, 1978 , p. 359). Educational measures and social activity play an important role on each stage of human life and have a direct impact on quality of life.

\section{Quality of life}

The notion "quality of life" is a multidimensional, ambiguous and vague at the same time. It concerns lots of life fields, so when concentrating on quality of life an individual one should approach that notion holistically as particular quality of life determiners interact and have vital influence on each other, e.g. a person's health influences social activity of an individual. So a disabled person is more endangered by social exclusion than a healthy person. There are multiple examples of mutual influence yet it is important that each change having impact on changing a particular indicator of quality of life carries certain consequences. An individual is responsible for changing particular factors so the notion of quality of life should be treated as a dynamic term, sensitive to each change, under the influence of both external and internal factors.

Reference materials give various definitions of quality of life. The research in the field was held by, among other, Farquhar (1995), Fernández-Ballesteros (1993, 1998), Abrams (1973), McCall (1975), Bowling (1995, 2005), Bowling, Seetai, Morris and Ebrahim (2002), Veenhoven (2000), Walker (2005), Campbell (1981), Michalos (1999), Michalos, Hubley, Zumbo and Hemingway (2001) etc. The concepts of those authors are different and present varied approaches to the problem of quality of life.

One of the most general definitions of quality of life is the one accepted by World Health Organization (WHO), according to which quality of life should be understood as "individuals' perception of their position in life in the context of the culture and value systems in which they live and in relation to their goals, expectations, standards and concerns. It is a broad ranging concept affected in a complex way by the person's physical health, psychological state, level of independence, social relationships, personal beliefs and their relationship to salient features of their environment" (World Health Organization Quality of Life (WHOQOL), 1995, 1405). That definition outlines the meaning of the notion very clearly although quite generally taking into consideration various aspects of an individual's life. Coping with the issue of quality of life one should be aware that its multidimensionality consists in accounting not only for chosen aspects of quality of life in its description but for all factors which have important influence on quality of life of an individual. Therefore, one should consider particular fields of human functioning: health, social, spiritual and environmental states (judged both subjectively and objectively). Those 
dimensions are vital and their influence on the feeling of the quality of life will change together with an individual's aging and will depend on the cultural approach to the perception of an individual in the society and on the expectations of the individual connected to his functioning in his old age. The feeling of quality of life is also influenced by a dynamically developed world and the ability of assimilation to the changes undergoing in it.

The available literature on the subject contains quality of life described from the point view of two components which are: objective conditions and subjective feeling. Objective factors comprise, among other, economic conditions, leisure time, social security, appropriate living conditions, natural and social environment and health. The other component is, i.e. subjective feeling concerns individual, "own" evaluation and assessment of various spheres of life and life itself as a whole taken in categories of satisfaction, happiness, hope, fear, loneliness, etc. Depending on the approach of authors of the definition of quality of life who take into account objective and subjective components in their description, they will contain more or less developed structural elements creating the components. Objective indicators of quality of life contain: age, gender, place of living, social-economic status, job, unemployment, relationships with others, marital status, children, health, events in life, religion, culture, civilization, political conditions, historical changes, climate, weather and seasons, diet and stimulants (Czapiński, 1992). However, the term of quality of life in a subjective feeling has a direct relation to the mental sphere of human functioning, i.e. the system of values of an individual, his or her aspirations, expectations and with requirements of social groups the individual cooperates with (Pikuła, 2015, 29). Subjective conditions will always refer to an individual assessment of life as a whole. The author of the concept of quality of life having two components was Robert E. Lane. According to his assumptions each factor: the subjective and the objective one may be characterized by nine elements. The subjective component of quality of life comprises of nine elements, which determine high quality of life. The group includes: (1) capacity for enjoying life, (2) cognitive, complexity, (3) a sense of autonomy and effectiveness, (4) self-knowledge, (5) self-esteem, (6) ease of interpersonal relations, (7) an ethical orientation, (8) personality integration, and (9) a productivity orientation. According to Lane's assumptions those nine elements describe the psychological state of the individual and are responsible for mental health and social responsibility. Those nine elements are called "quality of man" by Lane. They are responsible for subjective good feeling of an individual and social development. Objective elements determine the quality of environment (QC). Objective conditions reflect human chances to reach QP. According to Lane objective components include: (l) adequate material support, (2) physical safety and security, (3) available friends and social support, (4) 
opportunities for the expression and receipt of love, (5) opportunities for intrinsically challenging work, (6) leisure opportunities that have elements of skill, creativity, and relaxation, (7) available set of moral values that can give meaning to life, (8) opportunities for self-development, and (9) justice system that is managed by disinterested and competent parties. quality of life comprises both objective and subjective components (Lane, 1991; Lane, 1996). Therefore, one can say that while describing human quality of life one can take into consideration the fields of human activity influencing directly and indirectly his or her existence (Pikuła, 2015, 29).

From the perspective of this paper it is extremely important to present the psychological understanding of quality based on the need of updating (realisation) of oneself. The notion of realising oneself may be understood in lots of ways, as e.g.: using potential abilities hidden in the individual, more or less conscious realisation of life goals, playing social roles, such as family, professional or civic ones. In that sense the evaluation of quality of life consists in comparing expectations of an individual to reality. If our expectations are the same as reality or surpass it then we can speak about life contentment. The opposite situation, i.e. if discrepancies appear in the attitude towards expectations of an individual, we can speak about a negative life balance (Susułowska, 1986). That attitude is shared with the one presented by Veenhoven. The latter considers quality of life from the point of view of life opportunities and achieved results together with external and internal qualities, which enables him to extract four indicators of quality of life: (1) a possibly good environment for living, (2) individual's ability to live, (3) external usefulness of life and (4) internal life assessment. In his model the assessment of objective life conditions belongs to an outsider, e.g. a medical doctor, while the subjective assessment is seem as a personal assessment based on personal criteria of the individual. In that perspective there might appear a discrepancy of quality of life assessment as the objective assessment might be different from the individual's personal assessment (Veenhoven, 2000).

Defining quality of life on the basis of the theory of needs which has a vital meaning in the case of surveying quality of life in old age is a complement of understanding quality of life. According to some researchers "quality of life in old age is defined by the level os satisfying particular needs of seniors, among which such determiners of functioning as health (psychophysical fitness level), social contacts and participation in life (possibility to work and social activity, role realisation), having a family and relationships with it (loneliness and isolation levels), possibility of realising your own plans (self-management), autonomy, possibilities of self-creation and development (development of interests, passions, education)" (Fabiś, Wawrzyniak \& Chabior, 2015, 115). 
According to Tobiasz-Adamczyk (2009) one can enumerate three categories of quality of life indicators in old age. They include:

- functionality, which informs about the level of psycho-physical fitness,

- $\quad$ psychological state describing wellbeing, life happiness, satisfaction, optimism, belief in the future

- a scope of social interactions, in which a vital role is played by possessing a family, friends, satisfaction of social contacts and participation in social life (Tobiasz-Adamczyk, 2009, 69-77).

Tibitts, who took into consideration the factor of elderly people activity in his concept of quality of life, noticed a similar thing. From that perspective he claimed that the most important needs in the life of seniors are: (1) performing socially useful activities, (2) acceptance as a part of the society and a group and playing a certain role in them, (3) filling up most of the time in a satisfactory way, (4) keeping normal social contacts, (5) acceptance as a human being, (6) creating opportunities for self-expression and feeling of fulfilment, (7) a proper mental stimulation, (8) health protection and access to health care, (9) appropriately set lifestyle and keeping in touch with the family, (10) spiritual satisfaction (see Trafiałek, 2003, 107). According to the concept of quality of life in the theory of needs, satisfying all needs (both biological and social or cultural) is performed by various activities. The basic ones undertaken by seniors are:

- "recreational-hobby activity - shows in walks, sporting activities, garden work, painting, music, cinema, theatre, concerts;

- receptive activity - realised more in home conditions, e.g. watching television, listening to the radio, reading newspapers, magazines, books;

- $\quad$ publicly oriented activity - it is social and political activity;

- integration activity - it takes a form of meetings and various actions having a scientific-training, social meeting or charity character, i.e. meetings in old people's clubs, taking part in the University of the Third Age, meeting friends, charity work;

- other forms of activity - single forms of actions different from the former" (Wilk, 2007, 139-140).

Undertaking various forms of activity enables an individual to play social roles, functioning in a group and in the society. The consequence of lack of activity is a loss of acceptance on the part the environment, loneliness or social exclusion. Undertaking various forms of activity is conditioned by education, home environment situation, health, fitness, gender, place of living, etc. (SzaturJaworska, Błędowski \& Dzięgielewska, 2006, 161). 
The answer to the issue of old age quality of life enhancement is a concept of active aging developed by WHO, according to which "active aging is the process of optimizing opportunities for health, participation and security in order to enhance quality of life as people age" (World Health Organization (WHO), 2002 , 12). The concept of active aging aims at encouraging seniors to an active participation in social, educational, economic and cultural life. On of the basic pillars of the active aging concept is education. According to WHO, people who are better educated and who undertake educational activities adjust themselves better to the coming changes and are less often endangered by social exclusion. Education enables updating and supplementing knowledge, gaining and perfecting new skills, broadens awareness, fulfils therapeutic functions. Undertaking educational activity has a positive influence on functioning of a person in the society. Participation in educational classes has an impact on quality of life of seniors as, apart from equipping seniors not only with knowledge indispensable to proper organisation of everyday life and undertaking a healthy and active lifestyle, it enables them to make and keep new social relationships.

\section{Socio-educational activity of seniors in Poland}

Social and educational activity supplement each other. In the literature of the subject social activity is understood by "all socially standardised activities of individuals performed within certain social roles" (Zgliczyński, 2012, 134). Social activity of an individual is characterised by an active state of the individual which shows itself by influencing natural and social environment. That perspective has a very wide scope of meaning including activity fields connected to professional occupation, gaining knowledge, creativity, entertainment, participation in various social groups and the level of it is decided by internal and external factors of psychological, biological and social character (Zgliczyński, 2012, 134). By social activity one can understand social work, i.e. "participation in group activities surpassing the duties connected to performing professional and family functions aiming at realisation of precious social values" (Zgliczyński, 2012, 134). Social activity understood in such a way encompasses voluntary work as well. Hence, social activity may include various forms of actions: (1) cultural activity, (2) home-family activity, (3) professional activity, (4) social activity, (5) educational activity, (6) religious activity and (7) recreational activity" (Szatur-Jaworska et al., 2006, 163). Activity may be divided into: formal, informal and alone (Szatur-Jaworska et al., 2006, 161). In recent years in Poland more and more formal and informal institutions have originated where seniors can meet and undertake educational activity. They 
include Third Age Universities, OAP Clubs, Day Senior Centres, Praying Circles, etc.

The analysis of available data in scientific studies presents a hardly optimistic image of a Polish senior. Research undertaken by Iwona Mandrzejewska-Smól depicts that seniors most often listen to the radio and watch television programs and mainly undertake home-family activity. Further on there were religious and recreational activity. Educational activity is the least chosen type among seniors. The reason of that state is lack of time and willingness to undertake educational activity. The surveyed pensioners "saw neither a necessity nor a need to undertake educational activity. They generally acknowledged that pension was the time for relaxation. Furthermore, women indicated that lack of time for that activity was caused by their devotion to home and the family. Some of them proved their lack of motivation by the statement that "education is for young people and elders do not learn like young people" (Mandrzejewska-Smól, 2014, 201-212). Seniors who undertook educational activity justified that choice by the will to keep good mental condition, enhancement of life satisfaction feeling and a possibility of self-realisation (Mandrzejewska-Smól, 2014, 201-212). Taking into consideration the meaning and influence of education on quality of life in old age the results of the analyses are not optimistic and confirm the results of research run within CBOS (Public Opinion Research Centre).

According to the research run by CBOS the most often undertaken activity by seniors is watching television (98\%), meeting friends and acquaintances at home $(87 \%)$ or outside $(76 \%)$, religious activity $(81 \%)$, listening to the radio or music $(81 \%)$, reading books, magazines, newspapers (80\%), visiting family, relatives outside the seniors' place of living (77\%), walks and hikes (73\%). 55\% of pensioners works in their gardens, $44 \%$ takes care of grandchildren and greatgrandchildren, $34 \%$ help in running the household, $29 \%$ help in earning a living for the family, $22 \%$ take care of the ill and disabled members of the family,44\% of pensioners practise their hobbies and develop their interests, 35\% of the surveyed elders practise sport. Unfortunately this research also showed that only a small group of pensioners undertake educational activity ca. 8\% (to compare PolSenior research shows that only $1 \%$ of elders undertake educational activity, while according to SHARE only $2.5 \%$ of people over 54 undertakes suc an activity). The results of the elderly participating in cultural life and using modern technologies are not particularly good as well. Museums, galleries, or exhibition halls are visited by ca. $23 \%$ of the surveyed people, $22 \%$ go to the cinema, theatres, opera or concerts are frequented by $22 \%$ while modern technologies are used by ca. $23 \%$ of the pensioners. Only $12 \%$ of seniors devote time to social work for other people, local community, neighbours, their parish and only $2 \%$ of the surveyed elders are engaged in voluntary work. Relatively 
few people participate in an activity of some group, religious community (9\%) (Public Opinion Research Center (CBOS), 2012). Survey of Health, Ageing and Retirement in Europe (SHARE) research depict that the percentage of Polish seniors who do not undertake any of the social activities enumerated in the questionnaire reaches as much as $83 \%$. The most often undertaken activity is informal activity to the benefit of family and friends. SHARE research depict as well that social and educational activity decreases with age. "For example, the percentage of people declaring social activity drops from $21 \%$ among people between 55 and 64 to $11 \%$ among those of $65-74$ and to $5 \%$ among the oldest group of respondents. The exception is participation in religious activity where such a rule was not observed" (Chłoń-Domińczak, 2014, p.30). Town dwellers undertake social activity more often than country people. The presented data show that the most rarely chosen activity of elders is educational activity. They undertake family or alone activities most often. It is an important indication for people dealing with senioral policy in Poland the main aim of which should be supporting and ensuring a possibility of active aging in healthy state and ensuring high quality of life for the elderly. The concept of quality of life implies that undertaking socio-educational activity has big influence on life satisfaction of seniors. Undertaking educational activity by taking part in classes at the University of the Third Age enables not only broadening knowledge and skills of seniors but it influences intellectual, mental, social and physical enhancement of seniors, facilitates contacts with institutions such as health care, culture or rehabilitation centres and influences keeping social networks and communication among the elderly. Participation in classes of the University of the Third Age "prevents alienation of the elders from the society, facilitates development of their interests and passions, enables networking, allows those people to see themselves as full members of their society (...) and allows the seniors to make their lives more valuable, which, subsequently, causes the enhancement of its quality" (Zgliczyński, 2012, 140).

\section{Conclusion}

Various concepts of quality of life of seniors lead to a conclusion that undertaking socio-educational activity influences the enhancement of quality of life considerably. However, the research run within the issue implies that elders are unwilling to engage in educational activity while limiting their social activity to work in the circle of acquaintances and family. Therefore, the conclusion is that one should intensify operations for education to old age so that its positive value could increase. It is necessary to shape the awarness about positive impact of education on seniors' lives and on building new social relations. They are essential for the functioning of the elderly, because they have a direct impact on 
the particular components of quality of life. Educational activities have a positive influence on the skills of getting used to changes undergoing in the society including those referring to the process of aging. The process of aging of a human being does not need to destructively influence the quality of life of the elderly. Undertaking appropriate activities one can prevent diseases, smoothen the symptoms of aging and the worsening efficiency of the organism together with age. Worse functioning caused by healthy reasons does not need to impact social interactions negatively. Social interactions do not need to be limited to contacts with the closest family: children, grandchildren, who often have tight time schedules caused by, among other, professional obligations. The age and diseases which occur together with it do not necessarily need to influence our limiting each type of activity of an individual which has an important impact on the assessment of the subjective quality of life responsible for an individual assessment of life as a whole. Education only encourages to changes. Knowledge gives a wide range of possibilities of undertaking various types of activity. One can learn e.g. using modern technologies but to know how to use them one must first initiate steps leading to acquiring such competence. One can learn from each other even during organised meetings with friends. Summing up it is important not only to run education for the old age but it is crucial to educate for enhancing quality of life in old age. So far a dynamic change and technological progress contributed to adding years to life while educational activities should contribute to "adding lilfe to years" (Farquhar, 1995, s. 1440).

\section{References}

Abrams, M. A. (1973). Subjective social indications. Social Trends, 4, 35-56.

Bowling, A. (1995). What things are important in people's lives? A survey of the public's judgements to inform scales of health related QOL. Social Science and Medicine, 41, $1447-1462$.

Bowling, A. (2005). Aging well: Quality of life in old age. Maidenhead (UK): Open University Press.

Bowling, A., Seetai, S. Morris, R. \& Ebrahim, S. (2002). Quality of life among older people with poor functioning. The influence of perceived control over life. Age and Ageing Advance, 36, 310-315.

Campbell, A. (1981). The Sense of Well-being in America. New York: McGraw Hill.

Central Statistical Office of Poland (GUS). (2015). Sytuacja demograficzna osób starszych $i$ konsekwencje starzenia się ludności Polski w świetle prognozy na lata 2014-2050. Warszawa: GUS. Downloaded from http://www.opzz.org.pl/documents/1137115/0/ ludnosc_w_starszym_wieku.pdf

Chłoń-Domińczak, A. (Eds.). (2014). Portret generacji 50+ $w$ Polsce $i w$ Europie. Wyniki badania zdrowia, starzenia się $i$ przechodzenia na emeryture $w$ Europie (SHARE). Warszawa: IBE. Downloaded from http://eduentuzjasci.pl/publikacje-ee-lista/raporty/ 196-raport-z-badania/portret-generacji-50-w-polsce-i-w-europie-wyniki-badania- 
zdrowia-starzenia-sie-i-przechodzenia-na-emeryture-w-europie-share/1060-portretgeneracji-50-w-polsce-i-w-europie-wyniki-badania-zdrowia-starzenia-sie-iprzechodzenia-na-emeryture-w-europie-share.html

Czapiński, J. (1992). Psychologia szczęścia. Warszawa: Wydział Psychologii Uniwersytetu Warszawskiego.

Fabiś, A., Wawrzyniak, J. K., \& Chabior, A., Ludzka starość. Wybrane zagadnienia gerontologii społecznej. Kraków: Impuls.

Farquhar, M. (1995). Elderly people's definitions of quality of life. Social Science and Medicine, 41 (10), 1439-1446.

Fernández-Ballesteros, R. (1993). The construct of Quality of Life among the Elderly. In E. Beregi, I.A. Gergely, \& K. Rajzi (Eds.), Recent Advances in Aging and Science (pp 1627-1630). Milano: Monduzzi Ed.

Fernández-Ballesteros, R. (1998). Quality of Life: Concept and Assessment. In J. G. Adair, D. Belanger \& K. L. Dion (Eds.), Advances in Psychological Science. Vol.1 (pp. 387-706). East Sussex (UK): Psychology Press.

Kamiński, A. (1978). Studia i szkice pedagogiczne. Warszawa: PWN.

Lane, R. E. (1991). The market experience. Cambridge: Cambridge University Press.

Lane, R. E. (1996), Quality of Life and Quality of Persons: A New Role for Government? In A. Offer (Ed.), The Pursuit of the Quality of Life (pp. 256-294). New York: Oxford University Press.

Mandrzejewska-Smól, I. (2014), Aktywność edukacyjna jako główny wyznacznik aktywnego uczestnictwa w życiu społecznym osób w okresie późnej dorosłości. Przeglad Pedagogiczny, 2, 201-212.

McCall, S. (1975). Quality of life. Social Indicators Research, 2, 229-248.

Michalos, A. C. (1999). Reflections on twenty-five years of quality-of-life research, Feminist Economics, 5(2), 119-123.

Michalos, A. C., Hubley, A. M., Zumbo, B. D., \& Hemingway, D. (2001). Health and other aspects of the quality of life of older people, Social Indicators Research, 54(3), 239274.

Pikuła, N. (2014). Polimorficzność starości jako czynnik sprzyjający wykluczeniu. In L. Pytka, T. Zacharuk, \& E. Jówko (Eds.), Inkluzja społeczna jako remedium pedagogiczne w dobie kryzysu (pp. 309-316). Siedlce: Wydawnictwo UPH.

Pikuła, N. (2015). Poczucie sensu życia osób starszych. Implikacje do edukacji w starości. Kraków: Impuls.

Public Opinion Research Center (CBOS). (2012). Polacy wobec własnej starości). Warszawa: CBOS. Downloaded from http://cbos.pl/SPISKOM.POL/2012/K_094_12.PDF

Rutkowska, L. (2013). Trwanie życia w 2012 r. Informacje $i$ opracowania statystyczne. Warszawa: Główny Urząd Statystyczny, Departament Badań Demograficznych i Rynku Pracy.

Susułowska, M. (1986). Bilans życiowy ludzi starych. In I. Borsowa (Ed.) Encyklopedia seniora (pp. 97-102). Warszawa: Wiedza Powszechna.

Szatur-Jaworska, B., Błędowski, P., \& Dzięgielewska, M. (2006). Podstawy gerontologii społecznej. Warszawa: ASPRA-JR.

Tobiasz-Adamczyk, B. (Ed.) (2009). Przemoc wobec osób starszych. Kraków: Wydawnictwo Uniwersytetu Jagiellońskiego.

Trafiałek, E. (2003). Polska starość w dobie przemian. Katowice: Wydawnictwo „Śląsk”. 
Trusz, S. (2015). Aktywna starość i niemrawa młodość: zjawisko zagrożenia stereotypem a jakość funkcjonowania osób w podeszłym wieku, In K. Jagielska, A. Mirczak (Eds.), Starzejmy się w dobrym stylu (pp. 15 - 36). Kraków: Wydawnictwo „Scriptum”.

Veenhoven, R. (2000), The four qualities of Life. Ordering concepts and measures of good life. Journal of Happiness Studies, 1, 1-39.

Walker, A. (2005). A European Perspective on quality of life in old age. European Journal of Aging, 2, 2-13.

Wilk, T. (2007). Czas wolny w starości a jakość życia. In B. Juraś-Krawczyk (Ed.), Wybrane obszary badawcze andragogiki (pp.129-143). Łódź: Wydawnictwo Wyższej Szkoły Humanistyczno-Ekonomicznej.

World Health Organization (WHO). (2002). Active Ageing. A Policy Framework. Geneva: World Health Organization. Downloaded from http://apps.who.int/iris/bitstream/10665/ 67215/1/WHO_NMH_NPH_02.8.pdf

World Health Organization Quality of Life (WHOQOL). (1995). The World Health Organization Quality of Life Assessment (WHOQOL): Position paper from the World Health Organization. Social Science and Medicine, 41, 1403-1409.

Zgliczyński, W. (2012). Aktywność społeczna osób starych w Polsce w ramach wolontariatu i uniwersytetów trzeciego wieku, Studia BAS, 2(30), 129-150. 